\title{
Mitotic karyotype of the tropical freshwater crayfish Procambarus (Austrocambarus) llamasi (Decapoda: Cambaridae)
}

\author{
Jeane R. Indy ${ }^{1,2}$, Lenin Arias-Rodriguez ${ }^{1}$, Salomón Páramo-Delgadillo ${ }^{1}$, Ulises Hernández- \\ Vidal $^{1}$, Carlos A. Álvarez-González ${ }^{1} \&$ Wilfrido M. Contreras-Sánchez ${ }^{1}$ \\ 1. División Académica de Ciencias Biológicas, Universidad Juárez Autónoma de Tabasco (UJAT). Villahermosa, \\ Tabasco, México. C.P. 86150; leninariasrodriguez@hotmail.com \\ 2. Faculty of Fisheries and Marine Sciences, Sam Ratulangi University. Jl. Kampus Bahu, UNSRAT, Manado, Indonesia. \\ P.O.95115; jeanerimberindy@yahoo.com
}

Received 22-V-2009. C Corrected 06-X-2009. Accepted 01-XI-2009.

\begin{abstract}
In Mexico, the biology of Procambarus has been more studied than the biology of other Cambarids because of its diversity and potential use in aquaculture. We determined the karyotype of the Mexican tropical freshwater crayfish Procambarus (Austrocambarus) llamasi from 189 metaphase spreads from gill tissues of 17 adults. They had $98-120$ chromosomes (mode $2 \mathrm{n}=120$ chromosomes). There are 60 pairs of monoarm, telocentric chromosomes. Sex chromosomes were not detected and we propose that the P. llamasi karyotype can be used to distinguish this species from other Mexican crayfish. Additionally, we suggest using karyological data in aquaculture and conservation biology. Rev. Biol. Trop. 58 (2): 655-662. Epub 2010 June 02.
\end{abstract}

Key words: chromosome number, karyotype, tropical crayfish, Procambarus (Austrocambarus) llamasi.

There are three genera and about 50 species of cambarids in Mexico: Procambarus with 39 species, Cambarellus with 10 and Orconectes with only one species (VillalobosFigueroa 1983). In that country, the biology of Procambarus has been more studied than the biology of other Cambarids because of its diversity and potential use in aquaculture (Villalobos-Figueroa 1983, Diupotex-Chong et al. 1997, Rodríguez-Serna et al. 2000, 2002).

Since Villalobos-Figueroa (1983) reported the endemic distribution of the freshwater crayfish Procambarus (Austrocambarus) llamasi to the south-east region of Mexico, several studies have been done on its biology (Morales \& Bosada 1987), ecology (Morales et al. 1987, Villalobos-Hiriart et al. 1993), reproductive behavior (Mendoza 1994), reproduction (Rodríguez-Serna et al. 2000) and geographic distribution (Rodríguez-Serna et al. 2002).
However, studies on basic genetics like chromosome structure for karyotype determination are still rare, with exception of a study on $P$. diugeti which revealed a chromosome number of $2 \mathrm{n}=102$ chromosomes (Diupotex-Chong et al. 1997).

In general, cytogenetics studies of crustaceans are relatively few and very difficult to perform because their chromosome numbers are large (Niiyama 1962, Roberts 1969, Mittal \& Dhall 1971, Campos-Ramos 1997, Dumas \& Campos-Ramos 1999, Zhang et al. 2003, Lee et al. 2004), chromosomes are small and theirs shapes are very variable including metacentric, submetacentric, and acrocentric chromosomes (Tan et al. 2004, Salema \& Heino 1990, Damrongphol et al. 1991). Such distinctiveness makes them difficult to karyotype in comparison with the chromosomes of insects and some vertebrate species (White 1973). 
Early karyological studies have provided basic information on the number, size, and morphology of chromosomes which is an important prerequisite to the use of techniques for set chromosome manipulations in fishes (Arai 2001, Hulata 2001), marine crustaceans, such as the white shrimp Litopenaeus vannammei (Dumas \& Campos-Ramos 1999), and the Chinese shrimp Fenneropenaeus chinensis (Zhang et al. 2003), as well as in marine bivalves such as the Japanese oyster Crassostrea gigas (Allen et al. 1989). Consequently, information on the basic genetics of the tropical crayfish P. llamasi is necessary not only to reinforce its potential for aquaculture, but also for genetic improvements and conservation. The main aim of this study was to describe the mitotic chromosome number and karyotype of the tropical freshwater crayfish $P$. llamasi that inhabits the Grijalva River in Tabasco, southern of México.

\section{MATERIALS AND METHODS}

Sampling site and crayfish maintenance: Seven adult females and ten males of P. llamasi ranging from $5.5-14.0 \mathrm{~cm}$ of total length were used. Crayfish specimens were collected from the artificial creeks along the Academic Division for Biological Sciences of the Juarez University Autonomous of Tabasco (DACBIOL-UJAT); specimens frequently invade during the raining season (October-November) when the Grijalva River fills up with flood waters. Collected specimens were reared in the laboratory and fed daily with shrimp pellets throughout this study.

Cytological procedure and preparation of chromosome slides: crayfish specimens were processed following the procedure by Lakra et al (1997) and Arias-Rodriguez et al. (2007, 2008) with slight modifications as follows: Specimens were incubated for five hours in a well-aerated plastic bottle containing $10 \mathrm{ml}$ of freshwater that were mixed with $1.0 \mathrm{ml}$ of $1.0 \%$ colchicine solution. Then crayfish were sacrificed and gill tissue dissected out. Minced gill tissues were kept in hypotonic treatment with $1.0 \%$ sodium citrate for two hours at room temperature. Well swollen tissues were fixed in 4:1 fresh fixative solution made by chilled methanol $\left(4^{\circ} \mathrm{C}\right)$ and glacial acetic acid. Three changes were essential at the interval of $15 \mathrm{~min}$ to give appropriated fixation of the cytological tissue by a refrigerated $\left(4^{\circ} \mathrm{C}\right)$ centrifugation at 3000r.p.m for $10 \mathrm{~min}$. The tissues were kept then at $4^{\circ} \mathrm{C}$ for about one month.

Chromosome slides were prepared from the fixed tissues following the methods by Arias-Rodriguez et al. (2008) after adoption of the technique by Lakra et al. (1997) technique. The chromosome slides were stained for about $30 \mathrm{~min}$ in giemsa diluted at $10.0 \%$ with phosphate buffer $(\mathrm{pH}=7.0)$; and washed with distilled water before letting air-dry at room temperatures for 24 hours.

Microscopic analyses, karyotype assembling and classification: Well-spread mitotic metaphases were photographed using a Zeiss Axiostart plus microscope at $100 \mathrm{X}$ of magnifications by a coupled digital camera Sony Cybershot (DSC-W30). Diploid chromosome (2n) number or modal chromosome number was calculated on the base of the most frequently occurring measurement by counting the metaphases chromosomes.

Four of the best well spread mitotic metaphases were employed to assemble the most parsimonious karyotype of the species based on shape and measurements on chromosomes arms p (short arm) using Photoshop 6.0 (Adobe ${ }^{\circledR}$ ). The data-base was collected in the Microsoft ${ }^{\circledR}$ Excel-2003 for analysis and classification of karyotype formula as recommended by Levan et al. (1964). The ideogram was drawing on the basis of the averaged length of each homologous chromosome pair (p) and their centromeric position.

\section{RESULTS}

A total of 189 well-spread metaphases were scored from 70 analyzed chromosome slides from 17 adult specimens of the tropical crayfish P. llamasi. The mitotic counts ranged 
from $98(2.6 \%)$ to $120(67.7 \%)$ chromosome elements per diploid metaphase (Fig. 1). Basic statistical analysis indicated that modal chromosome number is $2 \mathrm{n}=120$ chromosome elements found in $67.7 \%$ of the 189 examined metaphases (Fig. 1).

A typical diploid mitotic chromosome spread of the tropical crayfish $P$. llamasi is shown in figure 2-A, and the most parsimonious karyotype of the species in figure 2-B. The average size of the 60 pairs of telocentric $(\mathrm{T})$ monoarm homologous chromosomes that comprise the karyotype of $P$. llamasi varied from the biggest pair one with $6.45 \pm 0.0 \mu \mathrm{m}$ to the smallest pair sixty with $2.15 \pm 0.30 \mu \mathrm{m}$ (Table 1 , Fig. 2). The chromosome formula proposed for P. llamasi is $2 \mathrm{n}=120$ telocentric (T) chromosomes (Table 1, Fig. 2). We did not detect any sex chromosomes (Fig. 2).

\section{DISCUSSION}

In cytogenetic studies, rapid growing tissues are required to obtain a large number of metaphase chromosomes spreads. Several karyological studies on crustacean have been performed from male gonad tissue (Murofushi \& Deguchi 1983, Chow et al. 1990, ChavezJusto et al. 1991, Damrongphol 1991, Xiang et al. 1994, Lakra et al. 1997, Tan et al. 2004). However, there are no available reports on karyotypes obtained from gill tissue of freshwater crayfish although the analysis of mitotic chromosomes provides a good tool to obtain the modal diploid chromosome number.

The mitotic procedure employed in this study allowed the establishment of the typical karyotype of $P$. llamasi that was characterized by $2 \mathrm{n}=120$ monoarm chromosomes. The karyotype structure of this species shares some chromosomal similarities like variation

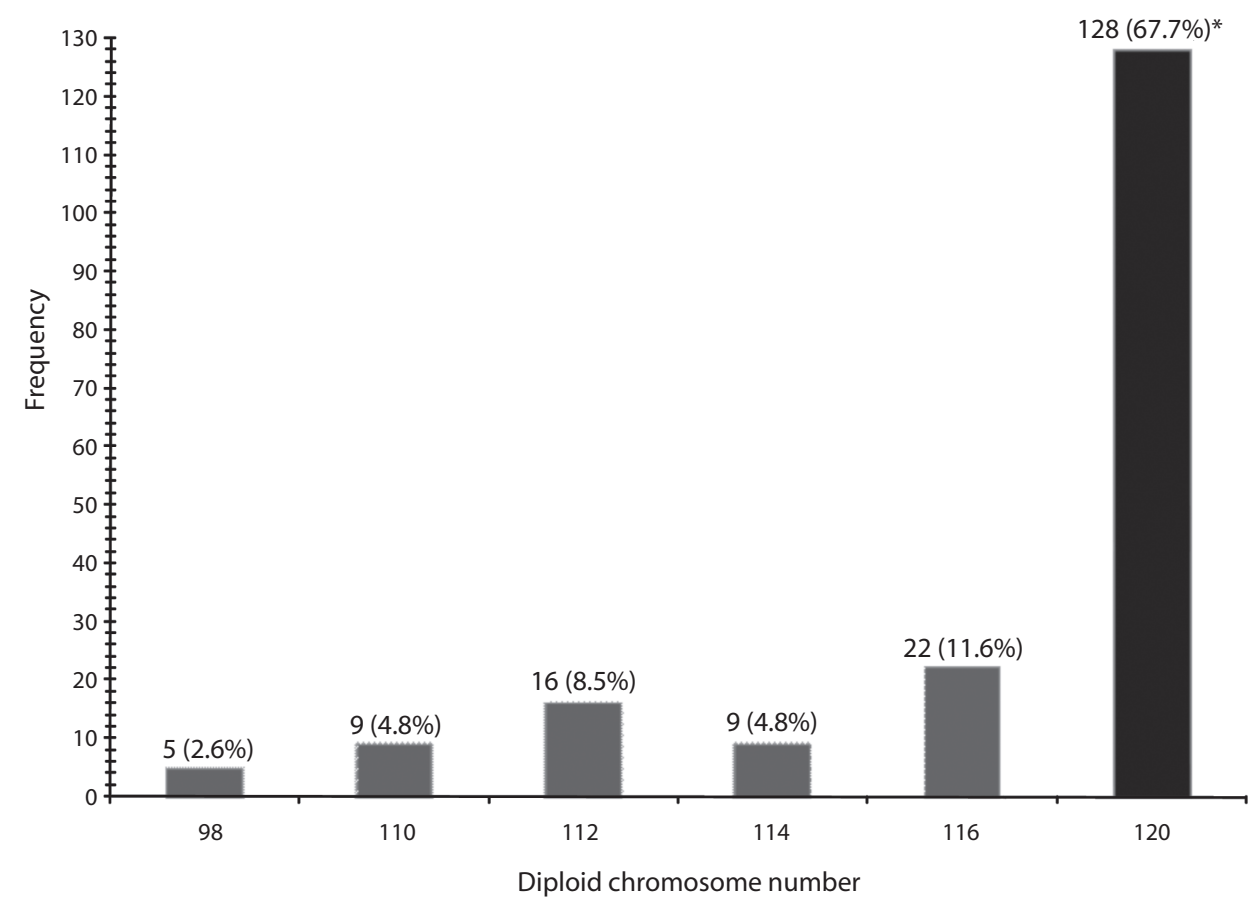

Fig. 1. Count distribution of chromosomes elements from gill tissue and diploid modal number (*) of $2 \mathrm{n}=120$ chromosomes in P. llamasi. 
TABLE 1

Length, relative length by chromosome pairs, and descriptive statistics for the karyotype of the tropical freshwater crayfish $\mathrm{P}$. llamasi

Chromosome pairs

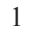

2

3

4

5

6

7

8

9

10

11

12

13

14

15

16

17

18

19

20

21

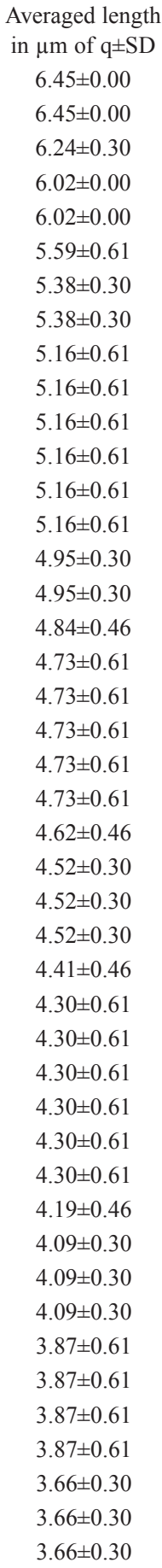

Averaged relative length of $\mathrm{q} \pm \mathrm{SD}$

$$
2.53 \pm 0.00
$$

$2.53 \pm 0.00$

$2.45 \pm 1.16$

$2.36 \pm 0.00$

$2.36 \pm 0.00$

$2.19 \pm 2.33$

$2.11 \pm 1.16$

$2.11 \pm 1.16$

$2.02 \pm 2.33$

$2.02 \pm 2.33$

$2.02 \pm 2.33$

$2.02 \pm 2.33$

$2.02 \pm 2.33$

$2.02 \pm 2.33$

$1.94 \pm 1.16$

$1.94 \pm 1.16$

$1.90 \pm 1.74$

$1.85 \pm 2.33$

$1.85 \pm 2.33$

$1.85 \pm 2.33$

$1.85 \pm 2.33$

$1.85 \pm 2.33$

$1.81 \pm 1.74$

$1.77 \pm 1.16$

$1.77 \pm 1.16$

$1.77 \pm 1.16$

$1.73 \pm 1.74$

$1.69 \pm 2.33$

$1.69 \pm 2.33$

$1.69 \pm 2.33$

$1.69 \pm 2.33$

$1.69 \pm 2.33$

$1.69 \pm 2.33$

$1.64 \pm 1.74$

$1.60 \pm 1.16$

$1.60 \pm 1.16$

$1.60 \pm 1.16$

$1.52 \pm 2.33$

$1.52 \pm 2.33$

$1.52 \pm 2.33$

$1.52 \pm 2.33$

$1.43 \pm 1.16$

$1.43 \pm 1.16$

$1.43 \pm 1.16$
Classification

$\mathrm{T}$

$\mathrm{T}$

$\mathrm{T}$

$\mathrm{T}$

$\mathrm{T}$

$\mathrm{T}$

T

$\mathrm{T}$

T

$\mathrm{T}$

$\mathrm{T}$

T

T

$\mathrm{T}$

T

T

$\mathrm{T}$

T

T

T

T

T

T

T

T

T

T

T

T

T

T

T

T

T

T

T

T

T

T

T

T

T

T

T 
TABLE 1

Length, relative length by chromosome pairs, and descriptive statistics for the karyotype of the tropical freshwater crayfish $\mathrm{P}$. llamasi

Chromosome pairs

45

46

47

48

49

50

51

52

53

54

55

56

57

58

59

60

Averaged relative
length of $\mathrm{q} \pm \mathrm{SD}$
$1.35 \pm 2.33$
$1.35 \pm 2.33$
$1.35 \pm 2.33$
$1.35 \pm 2.33$
$1.26 \pm 1.16$
$1.26 \pm 1.16$
$1.18 \pm 2.33$
$1.18 \pm 2.33$
$1.18 \pm 2.33$
$1.18 \pm 2.33$
$1.10 \pm 1.16$
$1.10 \pm 1.16$
$1.01 \pm 2.33$
$0.84 \pm 0.00$
$0.84 \pm 0.00$
$0.84 \pm 0.00$

Averaged relative

in $\mu \mathrm{m}$ of $\mathrm{q} \pm \mathrm{SD}$

$3.44 \pm 0.61$

$3.44 \pm 0.61$

$3.44 \pm 0.61$

$3.44 \pm 0.61$

$3.23 \pm 0.30$

$3.23 \pm 0.30$

$3.01 \pm 0.61$

$3.01 \pm 0.61$

$3.01 \pm 0.61$

$3.01 \pm 0.30$

$2.80 \pm 0.30$

$2.80 \pm 0.30$

$2.58 \pm 0.30$

$2.15 \pm 0.30$

$2.15 \pm 0.30$

$2.15 \pm 0.30$
Classification

\section{$\mathrm{T}$}

$\mathrm{T}$

$\mathrm{T}$

T

T

T

$\mathrm{T}$

T

T

$\mathrm{T}$

$\mathrm{T}$

$\mathrm{T}$

$\mathrm{T}$

T

$\mathrm{T}$

T

q:short arm, SD:standard deviation, T:telocentric chromosome according to Levan et al. 1964.

in chromosome number, variation in size and shape as in other crustaceans (Niiyama 1959, Murofushi et al. 1984, Lécher et al. 1995). For example, for $P$. clarkii two reported diploid numbers has been dated for similar species with $2 \mathrm{n}=192$ (Niiyama 1959) and $2 \mathrm{n}=188$ (Murofushi et al. 1984), while in the Cambaridae A. fluviatilis $2 \mathrm{n}=116$ (Lécher et al. 1995). Comparative chromosome data in other crustacean species is shown in Table 2. These studies suggest that the ranges of chromosome number in freshwater crayfish families (Astacidae,
Cambaridae, and Parastacidae) are larger than that reported for palaemonoid prawn (Table 2). Such cytological settings represent a methodological problem for cytotaxonomist who wants to employ karyotypical characters as taxonomic key for species identification.

Karyotypical studies are still absent for several Mexican species, but comparative data are now available based on the present report for the tropical crayfish $P$. llamasi and the $P$. diugeti studied by Diupotex-Chong et al. (1997). The reported fundamental number (FN)

TABLE 2

Comparison of diploid chromosome (2n) number among three families of crayfish

$\begin{array}{llcl}\text { Family } & \text { Species } & \text { 2n } & \text { Source } \\ \text { Astacidae } & \text { Astacus fluviatis } & 116 & \text { Lécher } \text { et al. } \text { (1995) } \\ \text { Cambaridae } & \text { Procambarus clarkii } & 192 & \text { Niiyama (1959) } \\ & \text { P. clarkii } & 188 & \text { Murofushi } \text { et al. } \text { (1984) } \\ & \text { P. digueti } & 102 & \text { Diupotex-Chong } \text { et al. (1997) } \\ & \text { P. (A) llamasi } & 120 & \text { Current study } \\ \text { Parastacidae } & \text { Cherax quadricarinatus } & 200 & \text { Tan } \text { et al. } \text { (2004) }\end{array}$



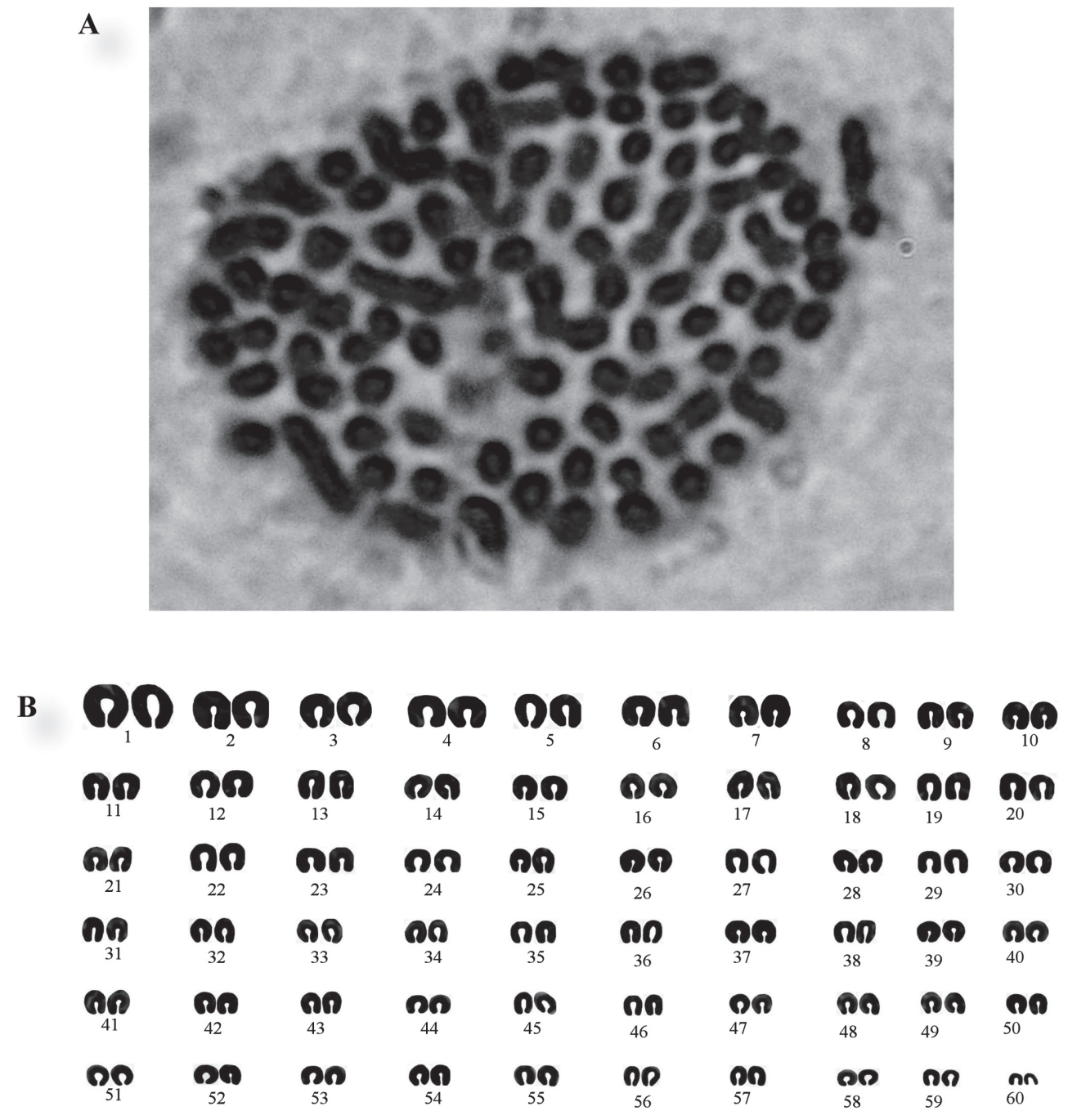

Fig. 2. Well-spread metaphase chromosomes of P. llamasi (A) and representative karyotype of P. llamasi with $2 \mathrm{n}=120$ telocentric chromosomes (B).

of 204 autosomal arms for P. diugeti (Diupotex-Chong et al.1997), suggests that described karyotype structure of $P$. llamasi with NF of 120 arms is a cytotaxonomical key to separate both species, because their chromosome constitutions are quite different in the compared species. In addition both studies revealed that the presence of sex chromosomes is not a cytological characteristic of crayfish karyotype. Studies regarding chromosomes number, morphological taxonomy and molecular tools are still needed in many Mexican crayfish species to understand the evolutionary processes that promote their radiation in Mexico. 


\section{ACKNOWLEDGMENTS}

Special thanks to Ingo Schlupp from Department of Zoology, Oklahoma University for his comments to this paper. This research was partially supported from PROMEP (UJATPTC-047), CONACYT (76305) and SEPCONACyT (79544) granted to L.A.R.

\section{RESUMEN}

El género Procambarus ha recibido mayor atención en los estudios de los principios fundamentales de su biología debido a su diversidad en el territorio mexicano y potencial uso en acuicultura. El cariotipo típico del acocil tropical mexicano Procambarus (Austrocambarus) llama$s i$, se estudió mediante 189 dispersiones cromosómicas en metafase del tejido branquial de 17 adultos tratados con la técnica citológica de inmersión. Encontramos un amplio número de cromosomas, que variaron entre 98-120 elementos cromosómicos, con número modal diploide de 2 n=120 elementos cromosómicos. El cariotipo del acocil tropical esta constituido por 60 pares de cromosomas monorrámeos, todos los centrómero están en la región telocéntrica de los cromosomas. En las metafases mitóticas de hembras y machos no fueron identificados cromosomas sexuales. Sugerimos considerar la estructura cromosómica del cariotipo como una herramienta citotaxonómica así como el empleo de datos cariológicos para propósitos de acuicultura y conservación del acocil tropical.

Palabras clave: cromosoma, cariotipo, acocil tropical, Procambarus (Austrocambarus) llamasi.

\section{REFERENCES}

Allen, Jr. S.K., S.L. Downing \& K.K. Chew. 1989. Hatchery manual for producing triploid oyster. University of Washington, Seattle, U.S.A.

Arai, K. 2001. Genetic improvement of aquaculture finfish species by chromosome manipulation techniques in Japan. Aquaculture 197: 205-228.

Arias-Rodriguez, L., J.P. González-Hermoso, H. FletesRegalado, L.E. Rodríguez-Ibarra \& G. Del VallePignataro. 2007. Cariotipos de los caracoles de tinte Plicopurpura pansa (Gould, 1853) y Plicopurpura columellaris (Lamarck, 1816) (Gastropoda: Muricidae). Rev. Biol. Trop. 55: 853-866.

Arias-Rodriguez, L., L. Ibarra-Castro \& S. Páramo-Delgadillo. 2008. Los cromosomas mitóticos y meióticos del pez tropical Petenia splendida (Pisces: Cichlidae). Rev. Biol. Trop. 56: 895-907.
Campos-Ramos, R. 1997. Chromosome studies on the marine shrimps Penaeus vannamei and P. californiensis (Decapoda). J. Crustac. Biol. 17: 66-673.

Chavez-Justo, C., M. Murofushi., M. Aida \& K. Hanyu. 1991. Karyological studies on the freshwater prawn Macrobrachium rosenbergii. Aquaculture 97: $327-$ 334.

Chow, S., W.J. Dougherty \& P.A. Sandifer. 1990. Meiotic chromosome complements and nuclear DNA contents of four species of shrimps of the genus Penaeus. J. Crustac. Biol. 10: 29-36.

Damrongphol, P., N. Eangchuan, S. Ajpru, B. Poolsanguan \& B. Withyachumnarkul. 1991. Karyotype of giant freshwater prawn, Macrobrachium rosenbergii. J. Sci. Soc. Thai. 17: 57-69.

Diupotex-Chong, M.E., N.R. Foster \& L.A. Zarate. 1997. A cytogenetic of the crayfish Procambarus digueti (Bouvier, 1987) (Decapoda Cambaridae) from lake Camecuaro, Michoacan, Mexico. Crustaceana 70: 875-885.

Dumas, S. \& R. Campos-Ramos. 1999. Triploidy induction in the pacific White shrimp Litopenaeus vannamei (Boone). Aquacult. Res. 30: 621-624.

Hulata, G. 2001. Genetic manipulations in aquaculture: a review of stock improvement by classical and modern technologies. Genetica 111: 155-73.

Lakra, W.S., P. Kumar, M. Das \& U. Goswami. 1997. Improved techniques of chromosome preparation from shrimp and prawns. Asian Fish. Sci. 10: 117121.

Lécher, P., D. Defaye \& P. Noel. 1995. Chromosomes and nuclear DNA of crustacean. Invertebr. Reprod. Dev. 27: $85-114$.

Lee, T.H., N. Naitoh \& F. Yamazaki. 2004. Chromosome studies on the mitten crabs Eriocheir japonica and $E$. sinensis. Fish. Sci. 70: 211-214.

Levan, A., K. Fredga \& A.A. Sandberg. 1964. Nomenclature for centromeric position on chromosomes. Hereditas 52: 201-220.

Mendoza, M. 1994. Hábitos reproductivos del acocil Procambarus (Austrocambarus) llamasi (Crustacea: Astacidae) en condiciones de laboratorio. Universidad y Ciencia 11: 149-157.

Mittal, O.P. \& U. Dhall. 1971. Chromosome studies in three species of freshwater decapods (Crustacea). Cytologia 36: 633-638. 
Morales, M. \& L. Bosada. 1987. Algunos aspectos de la biología del acocil reculador Procambarus (Austrocambarus) llamasi y consideración sobre su cultivo en el trópico húmedo mexicano, p. 201-211. In L. Bozada (eds.). Otros Recursos Alimenticos. Serie Medio Ambiente En Coatzacoalcos, Universidad de Veracruz, Veracruz, México.

Morales, M., L. Bosada \& A. Casanova. 1987. Prospección poblacional, distribución geográfica y aspectos ecológicos del acocil Procambarus (Austrocambarus) llamasi del sureste de Veracruz, p. 169-199. In L. Bozada (eds.). Otros Recursos Alimenticos. Serie Medio Ambiente en Coatzacoalcos, Universidad de Veracruz, Veracruz, México.

Murofushi, M. \& Y. Deguchi. 1983. A method for obtaining metaphase chromosomes from large shrimp-like crustaceans. Rep. Inst. Sci. Living, Nihon Univ. 9: 95-157.

Murofushi, M., Y. Deguchi \& H. Yoshida. 1984. Karyological study of the red swamp crayfish and the Japanese lobster by air-drying method. Proc. Japan. Acad. Ser. B 60: 306-309.

Niiyama, H. 1959. A comparative study of the chromosomes in decapods, isopods and amphipods, with some remarks on cytotaxonomy and sex-determination in crustacean. Mem. Fac. Fish. Hokkaido Univ. 7: $1-60$.

Niiyama, H. 1962. On the unprecedently large number of chromosome of the crayfish, Astacus trowbridgii Stimpson. Annot. Zool. Jpn. 35: 229-233.

Roberts, E.L. 1969. Studies on the chromosomes in the lobster, Homarus americanus. Crustaceana 16: 194196.
Rodríguez-Serna, M., C. Carmona-Osalde, J.L. ArredondoFigueroa \& M.A. Olvera-Novoa. 2002. Distribución geográfica de Procambarus (Austrocambarus) llamasi (Cambaridae) en la península de Yucatan. Hidrobiológia 12:1-5.

Rodriguez-Serna, M., C. Carmona-Osalde, M.A. OlveraNovoa \& J.L. Arredondo-Figueroa. 2000. Fecundity, egg, development and growth of juvenile crayfish Procambarus (Austrocambarus) llamasi (Villalobos, 1955) under laboratory condition. Aquac. Res. 31: 173-179.

Salemaa, H. \& T. Heino. 1990. Chromosome numbers of Fennoscandian glacial relict Crustacea. Ann. Zool. Fennici. 27: 207-210.

Tan, X., J.G. Qin, B. Chen, L. Chen \& X. Li. 2004. Karyological analyses on redclaw crayfish Cherax quadricarinatus (Decapoda : Parastacidae). Aquaculture 234: $65-76$

Villalobos-Figueroa, A. 1983. Crayfishes of México (Crustacea: Decapoda). Smithsonian Institution Libraries and the National Science Foundation, American Publishing, New Delhi, USA. 276 p.

Villalobos-Hiriart, J.L., A. Cantu, F. Díaz-Barriga \& E. Lira-Fernández. 1993. Los crustáceos de agua dulce de México. Rev. Soc. Mex. Hist. Nat. 44: 267-290.

White, M.J.D. 1973. Animal Cytology and Evolution. Cambridge University, Cambridge, United Kingdom.

Xiang, J.H., R.Y. Liu \& L.H. Zhou. 1994. Chromosomes of marine shrimps with special reference to different techniques. Aquaculture 111: 321.

Zhang, X., L. Fuhua \& J. Xiang. 2003. Chromosome behavior of heat shock induced triploid in Fenneropenaeus chinensis. Chin. J. Ocean. Lim. 3: 22-228. 